\title{
ECONOMIC IMPEDIMENTS TO A TALIBAN PEACE PROCESS
}

\section{JAMES WEIR and HeKMATUllah AZAMY}

James Weir, Ph.D., is a cultural anthropologist and cofounder of the Afghanistan Research, Consultancy and Cooperation Organization (ARCC), Kabul, Afghanistan. He can be reached at jimmyweir2012@gmail.com. Hekmatullah Azamy is a research analyst at the Centre for Conflict and Peace Studies (CAPS), Kabul, Afghanistan. He can be reached at hekmatullah.azamy@yahoo.com.

\section{Abstract}

An important question underlies the potential for a successful peace process in Afghanistan: If political negotiations between the Taliban leadership and the Afghan government succeed, will fighters in the field cease their activities, especially illicit funding practices, and accept government legal authority? Interviews conducted in early 2014 - well before the announcement of Mullah Omar's death or the appearance of Islamic State in the region-indicate that a wide gulf separates the motivations of low-level insurgents from their leadership's ideological objectives. The rank and file fight for multiple reasons, the most significant of which is the financial advantage of association with the movement. Recent studies of the economics of insurgency describe a crime-insurgency-terror nexus that applies to the contemporary Afghan context, albeit requiring adjustment to account for the distinctive political circumstances and wartime history of Afghanistan.

$\mathrm{R}$ ecent studies of the economics of insurgency describe a crime-insurgency-terror nexus that applies to the contemporary Afghan context. ${ }^{1}$ This article draws on research into violent extremism conducted in Helmand and Herat provinces in early 2014. Research began as an effort to understand the political grievances and objectives that lead Afghans to become insurgents. The goal was to identify policies and programs that would lessen divisions between rural communities, the Afghan government, and Taliban insurgents. The expectation was that a better grasp of the political concerns of rank and file insurgents could usefully inform peace efforts. Interviews indicate, however, that Islam-inspired political opposition to the Afghan government does not significantly motivate most insurgents, suggesting that the terms "Islamist" or even "insurgent" are becoming misnomers. Frustration with corruption and government patronage networks was widely acknowledged, but rarely expressed as sufficient justification to take up arms. Retribution for loss of family or pursuit of local political grievances inspired some fighters. Although most insurgents state a mix of motivations and justifications for support of the Taliban, and the most consistent factor emphasized-by Afghan government officials, Taliban, and villagers lacking any clear association — was financial.

Our research finds insurgents in Helmand and Herat provinces funded by a host of illicit sources, primarily poppy production, "Islamic" taxation, extortion of development projects and foreign military contracts, forced bill collection, and smuggling. Unlike the early years of the conflict, funding no longer primarily originates with leadership outside Afghanistan. Rather, funds flow from Taliban-controlled regions up the chain of command to the leadership and then become re-dispensed in the form of individual payments. This creates a sense of autonomy, and some frustration, among the rank and file and necessitates the senior leadership to violently enforce rigorous mechanisms to ensure compliance. ${ }^{2}$ These funding sources (described below) grew more lucrative as the conflict dragged on. No longer a means to sustain a violent insurgency, the practices have become integral to the political economies of Taliban-influenced regions and bring many villagers into association with the movement.

Meanwhile, fighters in the field, long resentful of the leadership's comfortable safety in Pakistan, had their allegiances further tested after learning that their leadership lied for two years about the death of the movement's supreme leader and then watched a power struggle unfold. Interviewee statements from early 2014 about the motivations and economics of the conflict indicate that ordinary foot soldiers are unlikely to lay down their arms easily and accept the government's legal authority, at least not based on a peace agreement that would expand the government's authority in exchange for concessions that primarily benefit the Taliban leadership. After 14 years of conflict, a political truce will likely entail, at least in the short-term, decreased incomes and increased uncertainties about the future for many fighters in the field. Intangibly, yet perhaps of greater importance, the end of conflict, especially in the absence of alternative livelihoods, will result in a loss of purpose, respect, and honor among home 
constituencies. For peace to take hold, illicit economic practices must be disrupted and replaced with viable, legal alternatives, or risk having these practices continued under the control of more radicalized, criminal groups.

Continuing uncertainty about the outcome of the conflict combined with distrust of most political leaders, after decades of lawlessness, insecurity, and limited economic alternatives, leave many ambivalent about the national political dimensions of the conflict. After initial optimism when a U.S. air campaign dislodged the Taliban, hope soured as former warlords were placed in power and the conflict deepened. Despite many substantial reconstruction successes, the international response also made the Taliban more potent, as U.S./NATO forces backed the return of warlords to government positions and development money funded pervasive corruption. The U.S. expenditure of USD110 billion for reconstruction, combined with a military cost estimated at USD1 trillion, occurred with insufficient oversight, planning, or grasp of ground realities. Afghans who successfully maintained ties to both sides of the conflict grew empowered, while the deepening flow of resources into the region created structural disincentives to ending the conflict. Particularly in Helmand, Taliban control of territory meant that poppy production could thrive, leading rural villagers, farmers, and criminals to insurgent association. Meanwhile, past opportunities to negotiate with or accommodate the Taliban leadership have been squandered. We find that opposing visions of Afghanistan's political future no longer define the present instability; instead, the greater obstacle to durable stability is curtailing the illicit funding practices that now predominate, particularly in remote rural regions, where insurgency creates income. ${ }^{3}$

The emphasis of respondents in Helmand and Herat on the financial motivations of the rank and file diverges from the explanations - offered by most leaders on all sides - of the insurgency as a fight to replace the Afghan government, to drive out foreign influence, and to enforce a radical form of Islamic governance. The current impasse is more clearly understood when set against three sequential, but related, changes that have occurred to the movement since its inception, here first presented in basic terms. In the first stage, nationalistic and faith-based ideology propelled the Taliban to power in the mid-1990s. In the second stage, following the U.S. intervention in 2001, retribution and revenge motivated many to return to the movement. In the present circumstances a third stage finds financial incentives displacing the importance of both ideology and retribution. Each side to the conflict seems fixed on continuing to present the conflict in ideological terms, perhaps because the financial realities of the conflict make all sides compromised. Widespread corruption
To better understand the political grievances and objectives that lead Afghans to become insurgents, we conducted research on violent extremism in Helmand and Herat provinces in early 2014. The expectation was that a better grasp of the political concerns of rank and file insurgents could usefully inform peace efforts. Interviews indicate, however, that the terms "Islamist" or even "insurgent" are becoming misnomers. Most respondents stated a mix of motivations and justifications for support of the Taliban. The most consistent factor emphasized-by Afghan government officials, Taliban, and villagers lacking any clear association-was financial.

among government leaders, made more problematic by poorly managed international largesse, have exacerbated long-standing local political divisions, particularly in Helmand province. In these circumstances, vulnerable, excluded, or antagonized communities joined insurgents largely because of the economic opportunities of association, and, to a lesser extent, to protect themselves from the Taliban. Political Islam or local and personal grievances remain relevant, but practical economic realities and opportunities after decades of conflict are the greater factor leading many to pursue self and community financial interest in the name of "insurgency". In light of this reading of current circumstances, our concern is that for stability to take hold greater attention must be given to stopping or controlling extra-legal practices. As long as insurgency remains a source of easy profit for many nonideological or politically alienated participants, a peace negotiation with the senior leadership may splinter the group even further, enabling criminal and more radical transnational Islamist groups to become an alternative to the Taliban, the most menacing of which now is Islamic State (IS). ${ }^{4}$

\section{Methodology and background}

This article is based on 60 interviews conducted in early spring 2014 with active, former, and imprisoned Taliban, government officials, and community leaders in Helmand and Herat provinces. 32 interviews were conducted in the regional capital of Helmand, Lashkargah, and surrounding districts, while 28 interviews were conducted in Herat City, with interviewees coming from nearby districts. Not coincidentlly, Helmand province is the most violent and insurgent-influenced province, the country's largest producer of opium, and site of the greatest expenditure of international funds. Herat province is strategically located in the west of the country, with Herat City a vibrant economic center closely connected to Iran and Turkmenistan through business and cultural connections. The governors of each province facilitated access to Taliban prisoners and to reintegrated former Taliban commanders and 
fighters. Members of the Provincial Peace Committee (PPC) and Provincial Joint Secretariat Team (PJST) also helped to arrange interviews with community leaders. Additional interviews were arranged through local channels with former and current Taliban commanders and high-ranking Afghan security officials. Former Taliban interviewees were asked to arrange interviews with their associates who are still actively fighting. Most interviews were conducted in person, and recorded, with a few conducted by phone.

Interviews took place between January and March 2014, supplemented by interviews and research conducted by Hekmatullah Azamy as part of his daily work as well as by a literature review. The purpose of the interviews was clearly explained to the respondents: to understand the concerns and grievances of the Taliban with the aim of identifying policies and practices that might mitigate conflict. Interviews were unstructured conversations that covered a variety of topics, including the motivations of Taliban fighters. Interviewees understood the interviews would be used for research or journalism. Due to the politically sensitive and dangerous circumstances, interviews were kept as open-ended discussions.

In Herat and Helmand provinces the primary sources of locally available insurgent funding are the drug trade, the Islamic taxes (Zakat and Ushr), extortion of international, government, and business contracts, smuggling of mineral resources across borders, and the collection of electric bills. These funding sources can overlap, for example Islamic taxes can be applied to profits from the drug trade or smuggling, while the line between taxation and extortion is thin, determined by circumstances and perceptions. Similarly, individual interviewees often mention multiple funding sources, but statements from interviews are included under only one heading. The descriptions of illicit funding sources are unavoidably incomplete. The practices described here occur mostly hidden from the purview of the state, while the continuing conflict makes rigorous quantitative data collection impractical. One aim of this article is to present sufficient information about these financial sources as a important factor, among many, to associate with insurgents.

\section{The drug economy}

According to the 30 October 2014 Special Inspector General for Afghanistan Reconstruction (SIGAR) report, Afghanistan produces more than 90 percent of the world's opium, valued at up to 15 percent of the country's gross domestic product, and generating employment for over 400,000 people - more even than the Afghan armed forces. Helmand province, where 32 of the interviews were conducted, produces an estimated 49 percent of Afghan opium or over one-third of the world's opium. As a result, poppy production dominates the local economy, connecting rural constituencies and the Taliban to the illicit global economy through transnational criminal networks. An important example is the opium trade as a factor that influences the Taliban's relationship with groups like the Islamic Movement of Uzbekistan (IMU) who facilitate the cross-border trade of the product through Central Asia and beyond. $^{5}$

A recent UNODC report indicates that from 2013 to 2014 the country's opium harvest increased by 17 percent, the largest crop on record, while the year before (2012-2013) production increased 36 percent and was valued at over USD3 billion. Opium production increased two and a half times since 2001, despite a U.S. expenditure of USD7.8 billion on fighting the drug trade over that same period. The money available due to poppy production on Taliban-controlled regions becomes dispersed across a wide network, ranging between itinerant day laborers and corrupt government employees to Kabul and Dubai-based drug kingpins. More than simply funding Taliban activities, the wide socio-economic reach of drug production creates disincentives to legitimate governance and to resolve conflict. ${ }^{6}$

In a 15 January 2014 statement made to a U.S. Senate Caucus meeting, SIGAR's Inspector General John Sopko said that all the gains made over the past 13 years "are now, more than ever, in jeopardy of being wiped out by the narcotics trade which not only supports the insurgency, but also feeds organized crime and corruption." With billions spent yet failing to curb drug production, both drug profits and the money spent to combat poppy create opportunities for collusion between and among villagers, criminals, insurgents, and government officials. For example, efforts at drug eradication are widely acknowledged to have targeted less influential communities, and protected more powerful actors, often those with ties to both the insurgency and the Afghan government. As a result, a popular perception is that international actors support government leaders who have recognized connections to drug producers who, in turn, pay the Taliban for protection. With the lines between illegal and legal actors blurred, poppy production appears to be neither meaningfully criminal nor indication of support for the Taliban as a political entity, while Taliban facilitation of the poppy economy creates wealth and political influence. $^{7}$

In recent years analysts have drawn attention to how the consolidation of drug cartels (based on poppy and hashish) and organized crime in Afghanistan has come to resemble a process found in Mexico and Colombia. A chapter in a 2006 UNODC/World Bank report devoted to the topic explains the 
"mafiazation" of the drug economy in Afghanistan, with profits concentrated in the hands of influential, largely hidden, actors, while the Taliban act as "protectors" of these criminal organizations that often originate around families. In our interviews, respondents explained that many Taliban groups are comprised of family members who fight collectively to earn more. "Families play a dominant role in the Taliban hierarchy; as a family group they make more money and have an unquestioned trust in each other," explained one respondent - an observation often repeated. ${ }^{8}$

One observer - Gretchen Peters - explains "that it is no longer possible to treat the insurgency and the drug trade as separate matters, to be handled by military and law enforcement, respectively ... For many rural Afghans the greatest perceived threat is crime and economic instability, not the insurgency per se." Based on her interviews she concludes that "more than 80 percent of those surveyed for this project believe Taliban commanders in the south now fight for profit rather than religion or ideology." She argues that the drug trade have changed the nature of the Taliban movement, making it difficult to distinguish anti-government activities from criminality and the pursuit of basic livelihood in compromised circumstances. Our own, more recent research indicates that this shift has become only more entrenched since Ms. Peter's research and asks about its implications for the future of insurgent-government relations. ${ }^{9}$

Insurgents seek areas and communities free of significant state intervention, where they can install their own form of governance, provide essential services, expand into adjacent territories, and prove themselves a viable alternative to state authority. Combining violence, governance, and otherwise illegal economic opportunities, the Taliban persuade and coerce those with limited ideological or political sympathy to associate, with monetary incentives a convincing factor. The Taliban are said by most not to be directly involved in the daily affairs of drug production, but instead administer, protect, and finance production, and transport or charge merchants and transporters for protection from both government and thieves. Respondents mention various forms of Taliban involvement, including attacks on government security check posts, diversionary strikes, planting improvised explosive devices (IEDs), and building defensive positions around poppy fields. Battlefield tactics have mutated over the course of the conflict to include the protection of drug refinement, storage, and shipment routes. There are reports of opium warehouses where merchants and traffickers store and withdraw opium and around which fighting can be most fierce. ${ }^{10}$

An Afghan general stationed in Helmand, asked about whether the local Taliban might join the government, responded: "High ranking Taliban make 10-fold the money I make," and as long as being Taliban remains so lucrative why would they join the government? "Commanders charge opium carriers and other smugglers PKR100,000 [Pakistani rupees] per vehicle to cross Taliban controlled territories. Why would the Taliban join the peace process? They are kings in their areas." Similarly, a high Afghan intelligence officer in Helmand said: "The fight will never end in Helmand because of three reasons: first the opium trade, followed by taxation and extortion." Taliban activities spike after the first poppy harvest in the spring of most years. The Taliban interviewed rarely made direct mention of the money made from the poppy economy, yet made frequent, often brash, reference to money from taxation and extortion of the Afghan government and international military forces.

Wakil Ahmed Muttawakil, the former foreign minister under the Taliban regime, explained, somewhat defensively, that the Taliban do not force ordinary Afghans to grow poppies, but acknowledged Afghan farmers are lured by the high return on poppies and do pay religious tax to the Taliban in return for protection. Due to the vast sums associated with poppy in a region otherwise devoid of industry or economic alternatives, the drug economy is a significant source of income for Taliban-influenced communities, one that thrives where the movement holds the greatest influence. But while proud of being active resistance fighters and able to generate an income, we find insurgents cautious about being associated with poppy production. Fighting a corrupt government and invading foreign forces can be honorable, even when the precise justification for violent resistance is unclear. Drawing profit from drug production is accepted as a material necessity, especially during wartime, but it does not in itself warrant respect. Given the size of the poppy economy, especially in Helmand, the frequent mention of money to be made as an insurgent, and the widely recognized wealth of some leaders, the connection between insurgency and drugs is undeniable. Insurgents likely deemphasize their involvement since it discredits their Islamic credentials, while government officials stress the connection between drug money and insurgency. ${ }^{11}$

\section{Islamic taxes}

Zakat, one of the five pillars of Islam, obliges Muslims with sufficient wealth to give back to the community (ummah) with money intended to help the poor. The Islamic taxes of Zakat (alms) and Ushr (tithe) are an important source of Taliban fundraising. Zakat is a tax on capital assets including money, agricultural goods, precious metals, minerals, and livestock at a rate between 2.5 and 20 percent. Ushr is usually a 10 percent tax collected at the time of agricultural harvest. Zakat is 
intended to benefit the poor, but some Muslim scholars also justify it to finance a jihad. Livestock and money from local and large businesses operating in Taliban influenced regions is a source of Zakat, while Ushr is particularly applied to taxing opium and hashish (marijuana) yields. ${ }^{12}$

Respondents made frequent mention of Taliban taxation. The collection or imposition of Islamic taxes is difficult to distinguish from extortion (discussed below) of protection money. The popular perception is that payment of taxes prevents Taliban attack or abuse, while, at least for some, it fulfills an obligation of faith. Government or international development projects are particularly subjected to taxation or extortion, as the sources of these projects are deemed worthy of abuse, but lucrative local businesses are targeted as well. These taxes, much like the protection of drug production, fund local Taliban cells and create a revenue stream that is sent up the chain of command to the Taliban leadership. In the early years of the conflict, funding was more likely to originate with donors from Gulf nations, local wealthy patrons, and the booty collected from large operations and then percolated down the chain of command to active rank and file members. But particularly in Helmand, due to the substantial combined income from the poppy economy, development projects, and shipping contracts to military bases, funding originates in the field and must be carefully monitored by a Taliban financial commission to ensure that monies collected are sent to the leadership.

Two additional observations about how the application of Islamic tax influences attitudes toward the insurgency warrant attention. Afghans report being forced, feeling obliged, or willingly offering payments to the Taliban. Whether by coercion or inclination, payment enforces a perception of distance from the Afghan government and of legitimacy for the Taliban presence. On one hand, the Taliban, in some communities, successfully collect money from residents and are able to dispense services, including quick and enforced legal pronouncements. On the other hand, government often struggles simply to ensure its own security and it can be ineffective in providing basic services, thus failing to demonstrate its legitimacy. As such, Islamic taxes must be seen not only as a source of income for the Taliban movement and the individual cells that collect them, but as an influence on the perceptions of nonaligned villagers who must carefully assess the political reach and military might of both government and insurgency in their communities, matters with sometimes dire livelihood and security implications.

We find communities who offer their own men to the Taliban as a means of lessening the demands of taxation while keeping the movement's more zealous members at a distance.
Several described joining the insurgency as "insider Taliban" to prevent "outsider Taliban" from imposing both their cultural and financial demands. The example of Kochi Amir (name changed), the son of important tribal leader, and himself a tribal leader, is telling in its pragmatism and ambivalence as villagers negotiate their security and livelihood in an environment where limited resources and powerful, unpredictable forces prevail. Kochi Amir explained that he selected his tribesman to join the Taliban to protect his community from more zealous Taliban who demand excessive taxes or impose their extreme cultural and religious standards. "We are not ideological fighters," Amir exclaimed. "I armed a group of youth from our village to serve in Taliban ranks. We take part in their activities to resist the permanent presence of outsider Taliban in our communities. Many Taliban are brutal and their presence can cause us heavy losses, both financial or in conflicts." At the same time, Kochi Amir continued, he supports the government as well, by helping to organize an Afghan Local Police (ALP) unit in his area. He told us that with ties to both sides, if either side captures men from his village, he has contacts he can work with to release them. As an influential leader without a formal role in the government or the Taliban, his allegiance is not squarely aligned with either side. His first responsibility is to his tribal community, acting as their public representative and negotiating for their welfare. In volatile circumstances, where neither the state nor the insurgents hold ethical or military authority, rural communities maximize ties across political divides in pursuit of security and livelihood.

Abdullah Charsi, a former Taliban leader who joined the government and has come to regret the decision due to the loss of income (and, presumably, prestige), proudly explained that as a Taliban he raised all the money he needed and was beholden to no one. "I started my opposition with two AK-47s ... I had no link with Pakistan or any other countries supporting Taliban. I sought the help of my tribesmen to provide shelter, food, manpower, clothing, and weapons. As I grew more powerful, Pakistan offered assistance by treating our wounded soldiers and even tried to place my group into larger Taliban fronts. At my peak, I had over 300+ fighters in eleven subgroups operating in four districts. Now that I am with the Afghan government, we live in crisis. I'm under mountain of debts living here in Herat City. As a commander I had power, money, men, and other facilities. Businessmen, voluntarily, sent me money, clothes, shoes, etc. I sacrificed everything for joining the peace process, but if this situation continues as it is now, I will go back to 'hills' and reassemble my group - they, too, are desperate, and it won't take an hour for me to gather them again." For him, as for many of the interviewed, the 
financial dimensions of the conflict make the boundary between insurgency and criminality porous and create ambivalence toward being for or against the government.

\section{Development projects and military supplies}

As the insurgency widened, poppy production and Taliban taxation took new meanings, growing more profitable where the Afghan government lost influence. But while opium and Islamic taxes are locally generated income sources for the Taliban that were prevalent before the international intervention, charging protection money on the transportation of military supplies and extorting international and government-sponsored development projects became new income sources that grew in tandem with the international response to the conflict. A troubling conclusion is that the international effort to fight the Taliban and to fund development projects - the very effort to win the "hearts and minds" of locals - became a significant source of Taliban funding and corrupt government practices, while exacerbating local tensions as select leaders received preferential treatment and excluded adversaries grew antagonistic. Taliban receiving funds from transportation contracts has been publicly documented since 2009, with a U.S. congressional report commissioned to document the practice in 2010. Little has been done to curtail these practices, and as international forces withdrew, SIGAR continued to complain that the Taliban generate funds from U.S. military transportation contracts. Beyond funding the Taliban and bringing Afghans into the movement for the money to be made from insecure circumstances, perhaps even more insidiously, the Taliban's ability to profit from foreign contracts indicated, especially to wavering segments of the Afghan population, that the international or government commitment was limited. An important concern in quickly evolving circumstances is that with international reconstruction and military funds drying up, the competition for funding sources is likely to result in an increased reliance upon alternative illegal funding sources, particularly poppy. ${ }^{13}$

Interviews indicate a consensus that it has become impossible to execute government or internationally sponsored development projects without payments that end up in Taliban coffers. Respondents explain that Taliban commanders approach project implementers asking for an obligatory 10 percent charge of project funding or face obstacles, including the likelihood of attacks. The practice is so widespread that company owners approach Taliban and voluntarily pay the 10 percent to ensure good relations. Some respondents explained that by paying sufficient taxes, businessmen can establish a monopoly over the execution of projects in areas, as the
Taliban then prevent competitors from operating in a region. Former and active Taliban group commanders in both provinces acknowledged this practice.

Rehman, a former Taliban commander, explained in a February 2014 interview in Herat province, how he funded his group through locally generated resources. He joined the peace process with 15 of his fighters in January 2014. (He was later killed by former fellow commanders after they lured him into a trap by expressing their interests to join the peace process, a recurrent problem for those who change sides.) Rehman began: "In my entire four years of fighting, I never asked any other country to pay us. Every penny we spent came from local villagers, big security companies, and state officials who were paying us not to attack them." Rehman at first worked with ISAF troops, but lost his job after information he provided resulted in an operation that killed and injured civilians. His account of serving on both sides of the conflict indicates again that an ideological or political commitment to either side is not a substantial factor.

Another former Taliban commander in Herat province explained that most of the projects in the district where his group was active were implemented through the National Solidarity Program (NSP) and that there was no project executed without paying the 10 percent obligation to the commander governing the area. The trucking cartels, supplying goods to ISAF, development projects, and the Afghan government, appear to all have been charged levies that benefitted the Taliban. After USD110 billion of U.S. money spent in reconstruction over 14 years, one must ask to what extent the war effort strengthened the Taliban and how the abrupt diminishment of resources in the countryside will influence the conflict as the country enters a "Transformation Decade," a phrase used by international actors and government officials to describe the post-2014 decade. Competition over limited resources appears poised to grow fiercer while potentially providing a fulcrum for groups like IS or international criminal networks. The practice of extortion or taxation of development projects and supply contracts had at least four negative effect: (1) funding the Taliban and their affiliates, (2) encouraging alienated men to join the insurgency for easy money, (3) lowering the quality of projects executed, and (4) blurring the clear separation of sides to the conflict.

Electricity bills, telecommunications, mineral extraction, and extortion and theft

The Taliban deny outright theft and extortion, but many of our respondents say both occur at various levels and in different forms. The group does not always demand cash from the drug lords and wealthy businessmen. Rather, in return for their 
protection and provision of government-like services, including the settlement of legal disputes, locally powerful patrons are asked to provide material resources, often items that require a complicated importation process that is beyond the means of many Taliban. Items requested include vehicles of all kinds, communications technology, weapons, medicine, and food. Such supplies, while required, also help to avoid the appearance of being overly driven by money. The Taliban tax villagers in a wide variety of circumstances. In Greshk district people explain that Taliban sometimes levy special taxes on households as they plan large-scale operations, in an amount between AFN4,000 to 5,000 (Afghanis) per household. Similarly, a vaccination manager working for the department of public health in a district of Helmand said that Taliban have asked him to pay AFN10,000 every month as part of a pension-like payment to the family of a Taliban fighter who was from the same village and was killed in a battle with Afghan National Security Forces. This government employee explains that he cannot continue his job without making payments.

Apart from those already discussed, there are additional funding sources for the Taliban. These tend to be less systemic, less lucrative, and more location specific. They include the collection of electricity bills, holding the functioning of telecommunications towers hostage to payment, the extraction of minerals, cross-border smuggling, and theft. In Kajaki district of Helmand, the Taliban have been known to collect electricity bills and people are said to be happy with these charges as they are less than actual usage fees. Telecommunications antennas are allowed to stand if Taliban are paid. Similarly, people hired to watch the antennas are often introduced by the Taliban or else the towers are subject to attack. Antenna guards are said to occasionally plant IEDs for the Taliban, without easy detection.

Afghanistan is estimated to have mineral reserves valued at USD3 trillion. Helmand and Herat have highly prized marble; in addition, Helmand has brown, white, and green onyx - the most expensive marbles found in Afghanistan. In Helmand province, as in other parts of the country, regions rich in minerals often fall under Taliban control. However, in many instances where advanced machinery and skilled labor are required, the Taliban and local communities extract resources inefficiently, employing crude and destructive methods to obtain a variety of precious and semi-precious stones, including marble. A government official in Helmand we interviewed listed marble as one of the reasons for continued insurgency in some regions. He explained that locals take up weapons and join insurgents to create insecurity so that smuggling can be conducted without government intervention.
Others complain about Pakistanis who illegally cross the border to extract the marble and leave behind wreckage when their activities are finished. Unlike the criminal practices described - that is, drug production, protection money, or extortion-mineral extraction, bill collection, and the taxation of local businesses are income sources that should benefit the Afghan government once wrested from Taliban influence. ${ }^{14}$

The evolution of insurgency in a war economy ${ }^{15}$

In the 1990s, the Taliban emerged from civil war promising peace, the rule of law, and Islamic governance. Afghanistan was then divided into rival mujahideen fiefdoms, with extortion, road taxes, and civil disorder rampant and battle lines drawn through urban centers. Initially the movement received wide support, as their success reining in the impunity of regional warlords and curtailing widespread criminal predation brought relative stability. The movement claimed to act in the name of nation and Islam, although their conservative cultural edicts and enforcement methods were troubling, especially when viewed from outside the country. At this first stage, the Taliban nevertheless were accorded a degree of moral authority, as the best of the available alternatives and as defender of those victimized by unscrupulous warlords.

In 2001, the U.S. quickly forced the Taliban from power. Many returned to homes in rural villages, while some settled in Pakistan. But over time, sidelined and often provoked by warlords-turned-government-officials, now backed by international actors, a resistance movement slowly took shape. One interviewee, a former deputy minister during the Taliban regime, told us: "The mistake Afghan government made was not engaging the Taliban in the new government; they felt isolated. Those Taliban that continued to fight used government abuse and disrespect as an opportunity to attract the former Taliban and inspire them to start opposition." As former Taliban began to take up arms, a new, younger generation-often those excluded from the resources visibly flooding the country and frustrated by government corruption and patronage networks - slowly joined the senior leaders. As this second stage took shape, the movement reemerged fueled by a combination of resentment, grievance, and revenge. The struggle to reclaim control of the government was a somewhat secondary motivation.

The years 2005 to 2006 mark a turning point. The Taliban escalated attacks and increased their territorial ambitions. International forces and reconstruction assistance responded with a "surge" that peaked between 2009 and 2011, in an effort to reassert control over contentious districts and win over wavering Afghan "hearts and minds." In areas where the Taliban succeeded to carve out territory beyond government 
control, poppy production and a host of illicit economic practices grew highly profitable. At the same time, the Taliban learned to tax and extort the unprecedented volume of international resources flowing across the countryside, while colluding with influential actors who had ties with both insurgents and the government. As the conflict lingered, vulnerable segments of Afghan society became uncertain about whether the Taliban or the Afghan government would ultimately prevail, while the Taliban clearly held the greater monopoly on indiscriminate or vengeful violence. In this third stage of the movement's evolution, financial incentives and basic human security became motivations for association. Ideological, political, or governance objectives became increasingly secondary concerns, with the exception of some senior leaders and radicalized participants.

\section{Conclusion}

Our research finds the Taliban at the center of a crime-insurgency-terror nexus: Criminal activities made possible by the political circumstances of a war economy, supported by a relatively small number of genuine anti-state actors, use a variety of tactics, including attacks aimed at spreading terror and intimidation, to deadly effect. The Taliban are an indigenous response to Afghan political history, an early inspiration for a global rise in a violent jihadi movement, and a by-product of an insufficiently planned Western effort to fight a "war on terror" without an adequate grasp of Afghan realities. The movement now more closely resembles a criminal franchise than a political enterprise, a loose collection of rank and file insurgent groups who ostensibly submit to the movement's authority for as long as they continue to see financial benefit. The senior Taliban leadership maintains many of the same claims they have for the past two decades, to be defenders of Islam, nation, and communities against threats that are now both foreign and local. But most of the rank and file profit from insurgency and insecurity, a reality both international actors and the Taliban leadership seem unprepared to acknowledge.

As Afghanistan enters its next decade, stabilization efforts must identify appropriate and internationally coordinated responses to a mix of destabilizing elements. While negotiations with the Taliban leadership are a welcome and necessary first step to ending the conflict, they are not sufficient. Peace talks should occur simultaneously with an effort to disrupt criminal networks and to establish legal economic alternatives. Anti-corruption practices, new national and international drug policies, effective, locally-specific economic and agricultural programs, creative approaches to researching and combating violent jihadi groups and criminal enterprises - to name some of the issues this research draws attention to - must accompany peace negotiations, based on a realistic assessment of ground realities and a long-term vision. By nearly all social and quality of life indicators, e.g., health facilities, educational enrollment, life expectancy, infant mortality, the country is in fact vastly better off than it was 14 years ago. Yet important challenges remain and need to be honestly assessed, more in terms of the changing contexts of a violent conflict and evolving local and geopolitical circumstances and less in terms of the professional interests of Western officials and the desired outcomes and time frames of international organizations. We conclude by summarizing a few basic observations and recommendations.

Development assistance in the countryside is becoming substantially reduced, while the Afghan government remains dependent on international funds for the foreseeable future. The withdrawal of international troops removes both an income source and ideological motivation, that, coupled with the cover- up of Mullah Omar's death over the past two years and the leadership crisis that has ensued, leave the movement's political foundations shaky. Mullah Akhtar Muhammad Mansur, Mullah Omar's successor, is as yet an untested leader. Although reportedly interested in peace negotiations, his long-term objectives are as yet unclear. ${ }^{16}$ As the new Taliban leadership establishes itself, a disillusioned rank and file contending with political and economic uncertainty, war fatigue, and new geopolitical configurations of jihadi groupsmost notably IS - all could contribute to an interest in negotiations with Kabul. However, an overly abrupt political agreement with the Taliban leadership, one that does not begin to address the political-economic circumstances of the countryside and the futures of today's foot soldiers, might result in IS filling a power vacuum. If enough Taliban refused to follow their leadership into a negotiation process, IS could recruit some of them, based on both ideological and financial incentives, while allowing farmers to grow poppy, and connecting locally sourced products-especially poppy, but also minerals, antiquities, and smuggled commodities-to international markets far more effectively than the Taliban have.

Political negotiations with the Taliban leadership should include finding solutions to the practices outlined above, most substantially to seek Taliban assistance in reining in the production of poppy, and generally helping the government to revert the wartime economy to a productive, legal, taxable, and sustainable course. Otherwise, the Afghan government will have to take strong measures, supported by violence, to rein in these practices. Poppy farmers need viable economic alternatives, while big smugglers must be aggressively 
confronted to the full extent of the law. A coordinated regional and international effort to lessen the demand of illegal opiates in Western countries and to intercept transnational smuggling routes, with particular attention paid to Afghan borders with Central Asia and Iran, will help mitigate the problem. Similarly, mineral resources and other illegally smuggled goods should be kept out of black markets by creating internationally recognized restrictions on their illegal export, and clear, verifiable mechanisms for their efficient extraction and transport into international markets. As many have argued, Afghanistan has tremendous potential to become a regional economic and transport hub, connecting energy-rich Central Asia to power hungry South Asia, even to western China, to Iran, and to warm-water ports on the Indian ocean. Materializing the economic potential of the region is an essential component to combat the present state of insurgency, especially for the rural, impoverished Afghan countryside, where an entrenched war economy has become the greatest incentive for association with the Taliban.

\section{Notes}

1. See, e.g., Peters (2009a); Makarenko (2012); Felbab-Brown (2013); Chayes (2015).

2. The Taliban layha (code of conduct) contains a description of mechanisms designed to prevent financial abuses; see Clark (2011).

3. Continuing uncertainty: Felbab-Brown (2013). Ground realities: SIGAR (2015).

4. Widespread corruption: Malkasian (2013).

5. 90 percent of world's opium: SIGAR (2014b); percent of GDP: AREU (2014).

6. Recent report: UNODC (2014). U.S. expenditure: Stancati (2014).

7. Sopko quote: SIGAR (2014a). Widely acknowledged: Peters (2009a); Malkasian (2013); Chayes (2015).

8. Mexico and Colombia: Petrich (2013). UNODC/World Bank report: See Buddenberg and Byrd (2006).

9. One observer: Peters (2009b).

10. Reports regarding warehouses: Malkasian (2013).

11. Former foreign minister: See Bashir (2014).

12. To finance jihad: Mission Islam (n/d); Malkasian (2013).

13. Publicly documented: Roston (2009); U.S. House (2010).

14. USD3 trillion worth of mineral reserves: Najafizada (2011).

15. This section is a further development of Weir and Azamy (2014).

16. Azamy (2015).

\section{References}

[AREU] Afghanistan Research and Evaluation Unit. 2014.
"Despair or Hope: Rural Livelihoods and Opium Poppy Dynamics in Afghanistan." Report for the European Union by Paul Fishstein. http://www.areu.org.af/Uploads/Edition Pdfs/1421E\%20Despair\%20or\%20Hope\%20Web\%20 Version.pdf [accessed 15 December 2014].

Azamy, H. 2015. "The Looming Coup Within the Taliban." Gandhara. 25 July 2015. http://gandhara.rferl.org/content/ afghanistan-looming-taliban-coup/27152087.html.

Bashir, M. 2014. "Afghan Taliban Trades Ideology for Profiteering." Gandhara. 5 April, 2014. http://gandhara. rferl.org/content/taliban-war-profiteering/26675311.html.

Buddenberg, D. and W.A. Byrd, eds. 2006. "Afghanistan's Drug Industry: Structure, Functioning, Dynamics, and Implications for Counter-Narcotics Policy.” Report No. 38931. Washington, D.C.: The World Bank. http://documents.worldbank.org/curated/en/2006/01/7444 645/afghanistans-drug-industry-structure-functioning-dy namics-implications-counter-narcotics-policy [accessed 24 September 2015].

Chayes, S. 2015. Thieves of the State: Why Corruption Threatens Global Security. New York: Norton.

Clark, K 2011. "The Layha: Calling the Taleban to Account." Afghanistan Analysts Network. http://www.afghanistananalysts.org/wp-content/uploads/downloads/2012/10/201 10704_CKlark_The_Layha.pdf [accessed 24 September 2015].

Felbab-Brown, V. 2013. Aspiration and Ambivalence: Strategies and Realities of State Building in Afghanistan. Washington, D.C.: The Brookings Institution.

Malkasian, C. 2013. War Comes to Garmser: Thirty Years of Conflict on the Afghan Frontier. Oxford, UK: Oxford University Press.

Makarenko, T. 2012. "Europe's Crime-Terror Nexus: Links between Terrorist and Organized Crime Groups in the European Union." European Parliament. Directorate General for Internal Policies. Policy Department C: Citizens' Rights and Constitutional Affairs. Brussels: European Parliament. http://www.europarl.europa.eu/ thinktank/en/document.html? reference=IPOL-LIBE_ET $\% 282012 \% 29462503$ [accessed 24 September 2015].

Mission Islam. [n/d]. "Zakat (Alms)." http://www.missionislam.com/knowledge/zakat.htm [accessed 4 January 2015].

Najafizada, E. 2011. "U.S., Afghan Study Finds Mineral Deposits Worth 3 Trillion.” Bloomberg Press. 29 January 2011. http://www.bloomberg.com/news/articles/ 2011-01-29/u-s-afghan-study-finds-mineral-depositsworth-3-trillion [accessed 1 December 2014].

Peters, G. 2009a. Seeds of Terror: How Drugs, Thugs, and Crime are Reshaping the Afghan War. New York: St. Martin's Press.

Peters, G. 2009b. "How Opium Profits the Taliban." USIP Peaceworks Report. Washington, D.C.: United States Institute of Peace. http://www.usip.org/publications/ rhetoric-ideology-and-organizational-structure-of-thetaliban-movement [accessed 5 January 2015].

The Economics of Peace and Security Journal — ISSN 1749-852X — http://www.epsjournal.org.uk

(C) EPS Publishing, 2015. All rights reserved. For permissions, email: ManagingEditor@epsjournal.org.uk 
Petrich, K. 2013. "The Drug Trade in Afghanistan and Pakistan: A Confluence of Crime and Terror." Freedom Observatory. 12 August 2013. http://www.freedom observatory.org/the-drug-trade-in-afghanistan-andpakistan-a-confluence-of-criminality-and-terror/ [accessed 16 December 2014].

Roston, A. 2009. "How the US Funds the Taliban." The Nation. 11 November 2009. http://www.thenation.com/ article/how-us-funds-taliban [accessed 10 November 2014].

Stancati, M. 2014. "Opium Cultivation in Afghanistan Hits Record." The Wall Street Journal. 12 November 2014. http://www.wsj.com/articles/opium-cultivation-in-afghan istan-hits-record-1415772002 [accessed 24 September 2015].

[SIGAR] Special Inspector General for Afghanistan Reconstruction. 2014a. "Future U.S. Counternarcotics Efforts in Afghanistan." Testimony before the Senate Caucus on International Narcotics Control. Statement of John F. Sopko. 15 January 2014. http://www.sigar.mil/pdf/ testimony/SIGAR-14-21-TY.pdf [accessed 24 September 2015].

[SIGAR] Special Inspector General for Afghanistan Reconstruction. 2014b. "Quarterly Report to the United States Congress." SIGAR: Arlington, VA. 30 October 2014. https://www.sigar.mil/pdf/quarterlyreports/201410-30qr.pdf [accessed 24 September 2015].

[SIGAR] Special Inspector General for Afghanistan Reconstruction. 2015. "Quarterly Report to the United States Congress." SIGAR: Arlington, VA. 30 July 2015. https://www.sigar.mil/pdf/quarterlyreports/2015-07-30qr. pdf [accessed 24 September 2015].

[UNODC] United Nations Office on Drugs and Crime. 2014. "Afghanistan Opium Survey 2014: Cultivation and Production." https://www.unodc.org/documents/cropmonitoring/Afghanistan/Afghan-opium-survey-2014.pdf [accessed 24 September 2015].

[U.S.House] U.S. House of Representatives. 2010. "Warlord, Inc. Extortion and Corruption Along the U.S. Supply Chain in Afghanistan." Report of the Majority Staff. Rep. John F. Tierney, Chair. Subcommittee on National Security and Foreign Affairs. Committee on Oversight and Government Reform. June 2010. Available at http://www.cbsnews.com/ htdocs/pdf/HNT_Report.pdf [accessed 23 September 2015].

Weir, J. and H. Azamy. 2014. "The Taliban's Transformation from Ideology to Franchise." Foreign Policy. 2 March 2015. http://foreignpolicy.com/2015/03/02/afghanistanstransformation-decade-depends-on-the-talibans-footsoldiers/ [accessed 23 September 2015]. 